\title{
The Boundary Tensions and Frontier Claims between Ethiopia and the Sudan, 1950s-1974: The Case of Sätit-Humära and Mätäma
}

\author{
Alemayehu Erkihun* \\ PhD Candidate of History at Bahir Dar University, Ethiopia
}

*Corresponding Author: Alemayehu Erkihun, PhD Candidate of History at Bahir Dar University, Ethiopia

\begin{abstract}
This paper critically examines the roots of boundary tensions and frontier claims between Ethiopia and Sudan with the special focus on Sätit-Humära and Mätäma from 1950s-1974.The stretch of Ethio-Sudanese frontier territories extending from the River Setit in the north to Mount Nefes Gebeya (the Sudanese called Jebel Halawi), Quara in the south, rarely inhabited until 1950s became very complex geographical zones, where dynamic conflicting interests and multifaceted developments intricate the territorial claims and boundary issues. Series of boundary negotiation between Emperor Menelik II and the British authorities, held from 1898-1902 ended up with causing vague and conflicting views on the Ethiopian and the Sudanese sides. Despite causing paradoxical views on both sides of the country, the Sudan-Ethiopia boundary demarcated by an Irish geographer, Major Gwynn in 1903 was not a hot political agenda of the two countries until the late 1950s. Unconditionally, the sections of the frontier territory stretching from Setit River to Mount Nefes Gebeya and the demarcations made my Major Gwynn appeared as sensitive issue in the late 1950s, when the imperial government established the mechanized agriculture in Sätit-Humära and Mätäma and the Sudan achieved its independence. With the conflicting understandings on the Gwynn line, attempts to demarcate/re-demarcate the boundary is unsuccessful so far. The boundary issue became the source of cooperation and dispute between the two countries. Boundaries are not only geographical limits, but also the ending point of the state sovereignty and power of the territorial jurisdiction. The boundary matters to any state and is a crucial factor because it determines sovereignty and provides strategic significance for military purpose and access to the external relation. The source material for this study is largely drawn from archival sources, housed in Gondar Town, the seat of the former Begemidir and Semien Governorate General. The originality of the source is objectively evaluated and carefully interpreted.
\end{abstract}

Keywords: Boundary, borderland, frontier, tensions, negotiationsa

\section{INTRODUCTION}

Border, boundary, frontier and borderlands sometimes appear synonymous. However, there is a conceptual difference between these terminologies. Barth defined that boundary is "officially sanctioned natural or artificial lines that divide territories on the ground and --- set limits that mark social groups off from each other." Thus, boundaries are the crossing lines, which separate sovereign states, while borders are "linear dividing lines, fixed in a particular space, meant to mark the division between political and or administrative units." ${ }^{2}$ Borders are the marking points of limits and the line of inclusion or exclusion of territory. Similarly, frontiers and borderlands interchangeably appear in some literatures. Frontier denotes an area found in the recognized geographical limit of the zone of a state. Martinez defined that frontier is an "area that is physically distant from the core of the nation: it is a zone of transition, a place where people and institutions are shaped by natural and human forces that are not felt in the heartland."

Boundary making and borderland management is not routine task; rather it requires legal frameworks, policy directions and political decisions. Boundaries are not simple lines, where one's territorial limit

\footnotetext{
${ }^{1}$ Fredrik Barth, (1999), “Boundaries and Connections.” In Signifying Identities: Anthropological Perspectives on Boundaries and Contested Values, edited by Anthony P.Cohen page, 17-36. (London: Rutledge ). 17

${ }^{2}$ Parker Bradley, 2006, "Toward an Understanding of Borderland Processes" American Antiquity, 71 (1), 79.

${ }^{3}$ Oscar Martinez, 1994, Border People: Life and Society in the U.S.-Mexico Borderlands (Tucson: University of Arizona Press), 3.
} 
ends and other's begins, rather it is a meeting point of diverse culture, creates differences in nationality, determines loyalty to the state and restricts limitless movement of citizens (requires a passport and entry visa). Moreover, boundaries are the defining belt of nationality and loyalty of the nationals to a particular state. Furthermore, boundaries serve as a protective line against security threats and unauthorized entry of goods and human immigration.

The boundary negotiation between Ethiopia and the Anglo-Egyptian Sudan started in the immediate post Adwa period with the coming of James Rennel Rodd led mission to Addis Ababa in April 1896. In fact, the settlement of the frontier claims moved no further progress; rather Rodd led mission had given much political space to the settlement of the Ethio-British Somaliland border problems. Carefully observing political developments on the Anglo-Egyptian side, Menelik II, self-schooled and uncompromising leader on the territorial integrity of Ethiopia dispatched his army to frontiers to incorporate Ethiopia's ancient territories along the south and north of the River Abay (Blue Nile) in 1898. In the meantime, the Ethiopian forces led by three notable personalities marched to the south and north of the Abay River to incorporate the frontier territories before the Anglo-Egyptians put the frontier regions under their sphere of influences.

Tensions grew between Ethiopia and the Anglo-Egyptians over the frontier territories. A month after the Anglo-Egyptian victory over the Mahdists, on 5 October 1898, Britain appointed John Lane Harrington as its official consul to Addis Ababa. Harrington was given the mission to follow up dayto-day political developments in Ethiopia and handle Emperor Menelik II diplomatically. In the meantime, Harrington informed the emperor that Britain had no any plan to occupy frontier territories, which had not been part of the Egyptian administration in the nineteenth century. ${ }^{4}$

With all the efforts, Menelik II and Harrington held the series of discussions to settle frontier claims and draw the stretch of boundary line from Todluc (the intersection of Ethiopia, Anglo-Sudan and the Italian Eritrea boundary) in the north to the Melile in the south. Harrington started inducing Menelik II to accept new frontier settlement proposal. In the meantime, the Anglo-Egyptian authorities issued that the whole territory between Abyssinia and the Nile belonged to Egypt and they let the emperor know this proposal. On 22 April 1898, Harrington and the emperor held discussion in Addis Ababa. In the meantime, Colonel Harrington came with the new proposal, drawing a line on sketch map from Todluc to Melile. Accordingly, contested frontier areas such as Hamran, Kedaw, Gallabat, Debana, Dar Sumati, Dar Guba, Dar Gumuz, and Bella-Shangul remained to Anglo-Egyptian-Sudan. ${ }^{5}$ The emperor rejected this arrangement and responded that all these frontier territories belongs to Ethiopia historically, parts and parcels of the Ethiopian empire since the earlier periods.

Moreover, frontier claims and borderland tensions between Ethiopia and the Anglo-Egyptian-Sudan heightened over Mätäma and Benishangul in particular. The emperor found that Benishangul was resource rich territory and provide strategic significance. The emperor's quest for Mätäma was emanated from historic claim and legitimacy.

With this in mind, Harington and Menelik II agreed to limit their further expansion and continue the boundary negotiation based on the principle of effective occupation. To this end, in 1898, Britain appointed an Irish cartographer Major Gwynn and Captain Austin to conduct preliminary field survey. The former was assigned to survey the frontier territory from the River Sätit in the north to the Sobat River in the south, while the latter was instructed to study south of the Sobat River as far as the Lake Turkana. Based on the preliminary survey reports, Colonel Harrington and Menelik II signed the boundary agreement on 15 May 1902 in Addis Ababa, which the terms of the agreement were concluded under five major articles.

Article I of the treaty describe the stretch of boundary from Khor Um Hajer in the north to Melile in the south, where the line passes through Gallabat, the Blue Nile, Baro, Pibor, Akobo as far as the intersection of six degrees north latitude and thirty five degrees east longitude. Article II describes the issues of representation during the demarcation. It states that the demarcation of the boundary

\footnotetext{
${ }^{4}$ A letter written by Colonel Harrington to Emperor Menelik II, dated on 9 and 21 Tehisas 1891 (18 and 30 December 1998) in PawulosGnogno. 2010, "AtseMenelikBäWučHagaratYätätsatsafuačäwDäbidabewoč" (Letters of Emperor Written to Foreign Countries). Addis Ababa: Aster Nega Publisher,

${ }^{5}$ Marcus, Harold, 1963, "Ethio-British Negotiations concerning the Western Border with Sudan, 1896- 1902" The Journal of African History 4 (1), 88.
} 
between the two countries would be commenced at the presence of representatives from the Ethiopian and the British sides, while Article III provided Britain with exclusive right for the utilization of the Blue Nile and its tributaries. Article IV and article V defines the British economic privilege over Ethiopia's western frontier territories. Accordingly, Ethiopia agreed to lease four hundred hectares of land in Gambella to Britain only for commercial purpose. In article IV, concession was given to Britain to establish commercial stations in Gambella, serve only for commercial purpose, not for military and political mission and the concession would be practical as long as the British rule in the Sudan was continued. ${ }^{6}$ The last article provides privilege to Britain to link its two colonies, Sudan and Uganda through railway passing through the territory of Ethiopia.

Commencing from the intersection of the Rawiyan and the Sätit Rivers (north) to the Melile (south) Major Gwynn alone demarcated the boundary of the two countries in 1903.The demarcation was unilaterally carried out by the only one side, left several resource rich and strategic sites on the AngloSudanese sides. In some areas, especiallyalongSätit-Humäraand Metema, Major Gwynn intentionally left Ethiopia's land, 30-40 kilometers on the Sudanese side. Towards the territory of Quara, the emperor and Harrington agreed to draw the line passing through the top of Mount Daglash (Ethiopians called it Nefes Gebeya).To the north of this mountain, the virgin lands such as Mertrahid, Qulit, Askinet, Lominat, Forgena, Zinjero Gedel, Sigara Terara and Tiha were left to the Sudan. Neither the Ethiopian local people nor the government had recognized the Sudanese claim for these territories.

\section{ROADS LEAD TO FRONTIER CLAIMS AND BOUNDARY TENSIONS}

Although the Ethio-Sudanese boundary negotiation was culminated with causing unending controversy and the legacy of far reaching consequences, the Gwynn lines caused no immediate public protest from the Ethiopian side. Frontier claims and the quest for re-demarcation were a hot agenda, neither in Ethiopia nor in the Sudan until the late 1950s. The frontier territories on the both sides of the borderwas uninhabited and agricultural activities were less practiced. Claims for the ownership of frontier farmlands appeared since the late 1950s, with the beginning of the agricultural revolution in Setit-Humera and Metema, large scale mechanized farming supported by tractors produced for marketing purpose. ${ }^{7}$

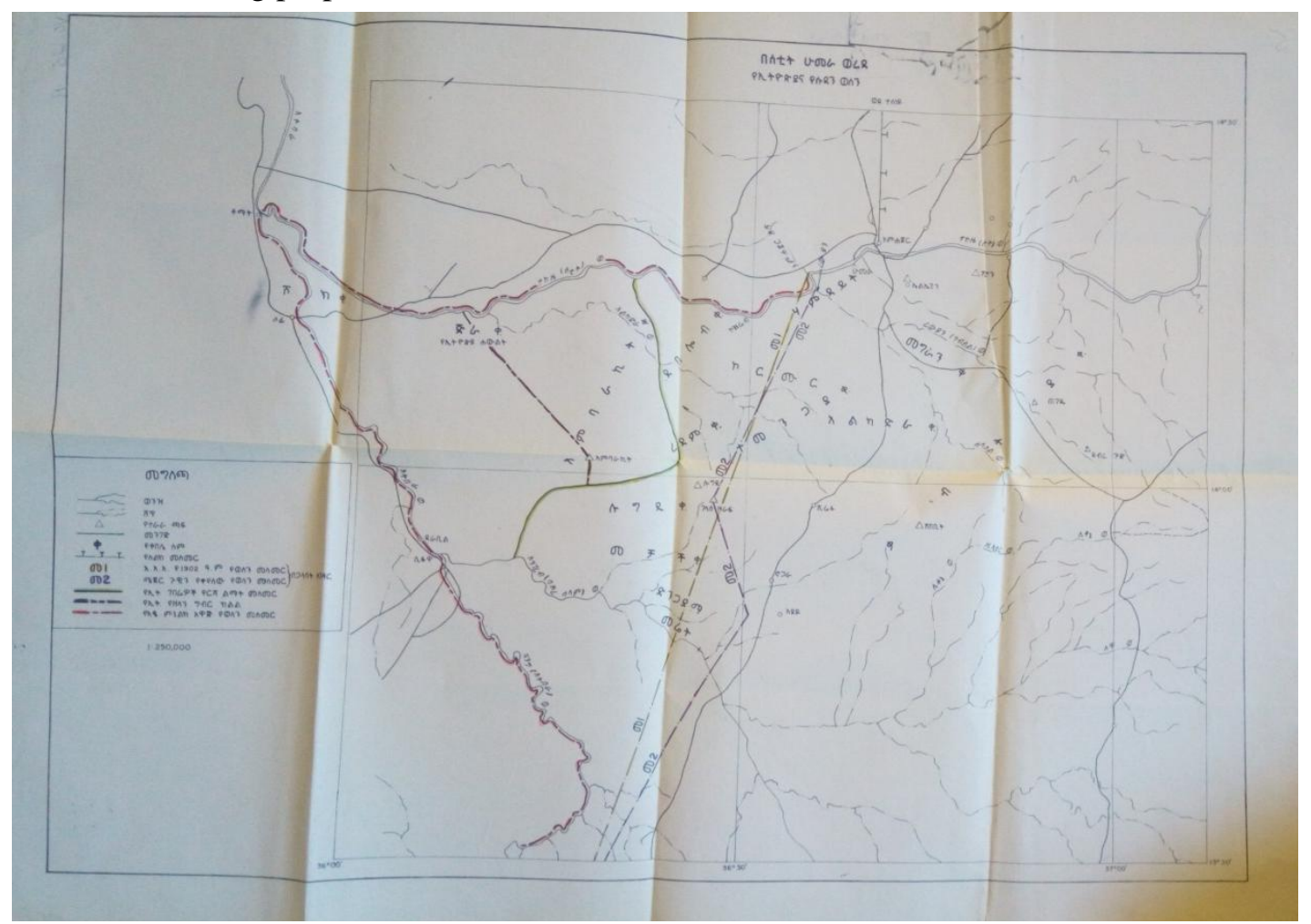

Map1: The contested borderland zones along Setit Humera

\footnotetext{
${ }^{6}$ Ian Brownlie, 1979, African Boundaries: A Legal and Diplomatic Encyclopedia (London: Christopher Hurst), 864. ${ }^{7}$ North Gondar Administrative Zone Archive, (Here after (NGAZA, Folder No.4/7/35/, File No. 388/1964; NGAZA, Folder No.L/7/8427, File No. 4331/1964).
} 
Source: NGAZAFolder No U/5, File No. L/7/35/1967.

With this agricultural revolution, the ristland owners of Welqait and Armachiho possessed the vast and virgin frontier areas in between the River Angereb and Setit such as Mechach, Lugdi, Redam, Gelan Zeraf, Deblob, Amberkit, Miol Meda, Kormur and Alkadra.Besides, the Ethiopian government leased frontier territories in Setit-Humera to several domestic cash crop producers and some foreign nationals

Similarly, the eastern bank of the River Guang such as Delelo, Dirmaga, Girar Wuha, Kor Homer, Shimalagara, Abu Tir, Gelaluban, Sennar, Koredam, Bahre Selam as far as the River Angereb, rapidly owned by the ristland owners of Aramchio and offered to the veteran solders and different sections of society including civil servants for cash crop production.

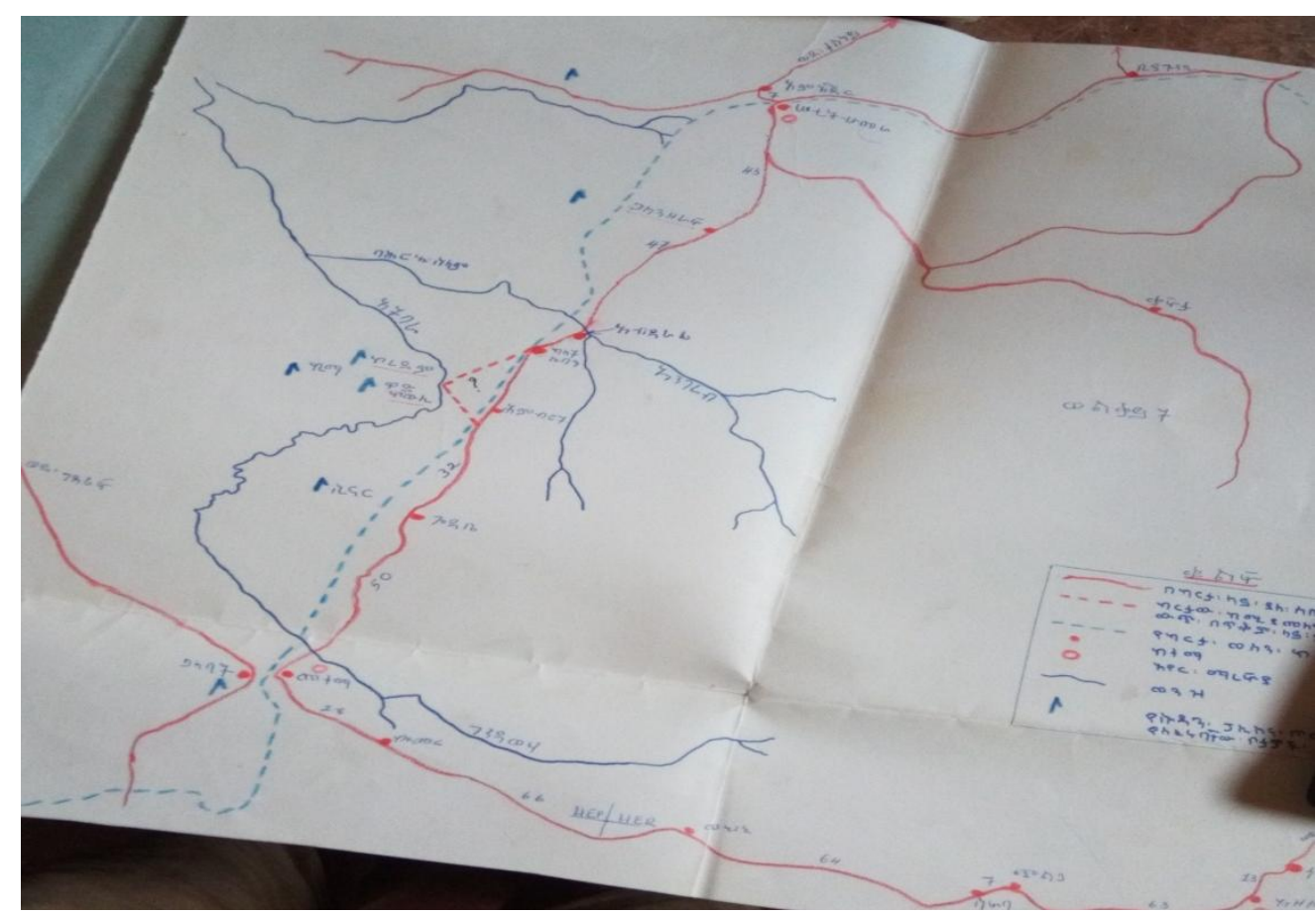

Map2: The contested areas along the River Guang Metema and Abderafi-Godebe

Source: North Gondar Administrative Zone Archive Folder No U/5, File No. L/7/35/1967,

In addition, in both Setit-Humera and Metema, the government provided large scale farm lands to the returnees of Korea and Congo peacekeeping forces. Eventually, peasants from the neighboring districts facing with the shortage of the farmlands, recurrent drought and famine such as Lay Gaynet, Ebinat, Belesa, Meket, Simada, Shire, Adwa, Aksum and highland Eritrea migrated towards uninhabited frontier areas of Setit-Humera and Metema since the late 1960s.

As a result, clash over the farmlands appeared between the Ethiopian and the Sudanese peasants settled on both sides of the border. The concept and the understanding of ownership to particular farmlands on the Ethiopian and the Sudanese sides contradict each. On the Ethiopian side, the government and the people knew that the Guang is a natural boundary between the two countries, where Ethiopia had been administering since time immemorial. Towards, Setit-Humera, both the government and the people knew that Ethiopia's boundary extends as far as the intersection of Guang and Setit (Tekeze also called Atbara) as far as Jira. On the contrary, the Sudanese people and the government drew the attention to the Gwynn line and claimed all the said lands located outside the boundary of the Gwynn line. When the Ethiopian peasants expanded their farmlands towards the west, the Sudanese peasants responded by setting fire to the crops, arresting peasant producers, confiscated oxen and crops. The eastern side of the River Guang valley was in special focus of the Sudanese government, rich in soil and conducive for tractor plow. In Setit-Humera, farmland claims and disputes run out of the management over Umberga and the Al-Fashaqa triangle, Ethiopians called in Setit or Maziga.

The Ethiopian borderland people were seriously complaining the Sudanese expansion towards SätitHumära and Mätäma and threats such as confiscation of the property, damages on crops, burning 
house, killing people, etc. ${ }^{8}$ The speedy mobilization of the Sudanese police forces along the border areas and the continuous violation of the status quo witnessed on the Sudanese side posed the security threats to the frontier people of Ethiopia and territorial integrity. In response, the Ethiopian government started arming the näč-läbaś units, local security forces in Sätit-Humära, Mätäma and Quara districts in the early 1960s. Arming the näč läbaś units was seen as an alternative way to save the frontier people from the constant threats sentenced by the Sudanese police forces. ${ }^{9}$

However, the local näč läbaś forces were poorly armed and failed to provide the frontier people with security protection. In April 1967, the Sudanese border security police confiscated several tractors and several quintals of sesame and cotton, imprisoned more than three hundred and sixty five Ethiopians, killed peasants and set fire on the peasants' house in Sätit-Humära frontier. The incident caused public protest in Sätit-Humära. They expressed their grievances to their government through public demonstration.

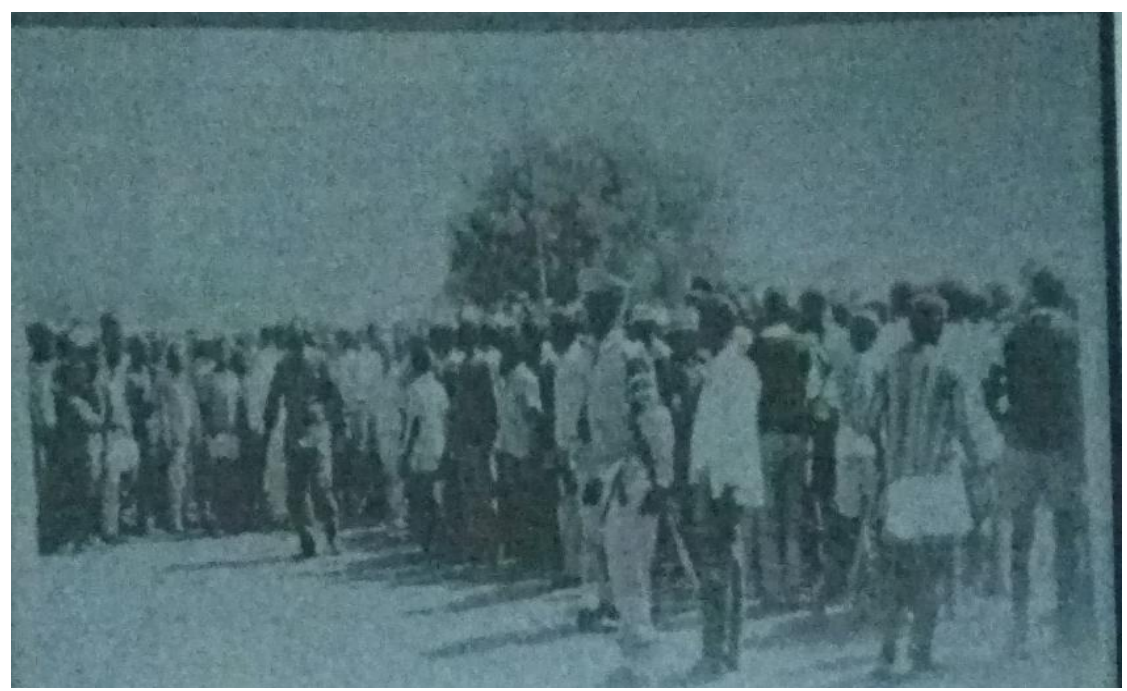

Picture1: Public Demonstration in Humera

Source: NGZAC, File Name- optoof h th

The demonstration was organized by the rist-land owners of Wolqayet and Tägädie, who lost their rist-lands to the Sudanese. They asked their government to free them to take retaliation measure against the Sudanese. In addition, they asked their government to take revenge actions, return the confiscated property and induce the Sudanese government to release prisoners. ${ }^{10}$ The peasant demonstrators agreed each other to take revenge measures if their government failed to retaliate. The news of the Sudanese action in Sätit-Humära alarmed Emperor Haile Sellasie personally. Shortly, the emperor dispatched five hundred police forces drawn from Addis Ababa led by Brigader General Yimam Goshu to Sätit-Humära. The emperor instructed Yimam Goshu to do all the best with his

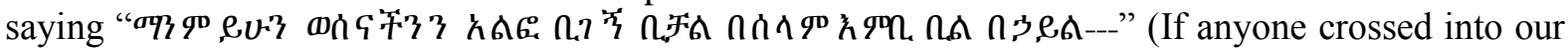
territory, peacefully if possible, forcefully declined to accept---). ${ }^{11}$ In May 1967, these police forces were deployed inGällan Zäraf, Rädam and Abderafi, located at fifty, twenty, and ninety kilometers far from the main site, Sätit-Humära respectively. The new police force was instructed to do better if the Sudanese border security and peasants threatened the Ethiopian frontier communities and their agricultural projects. Regarding the need for deploying the police in Sätit-Humära borderlands, local reports stated that:

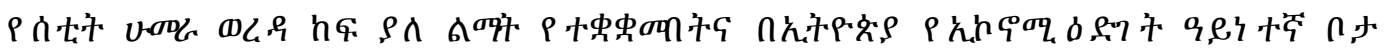

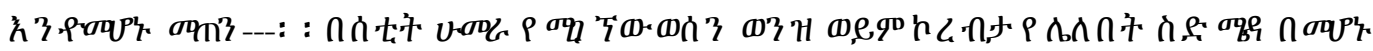

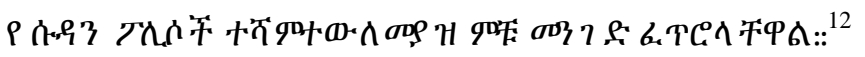

\footnotetext{
${ }^{8}$ NGAZA, Folder No, L/7/, File No.8178/1960).

${ }^{9}$ NGAZA, Folder No.L//7/8/, File No. 14935/1963; NGAZA, Folder No. L//7/8427, File No.4331/1964).

${ }^{10}$ NGAZA, Folder No, L/35, File No.459/1962.

${ }^{11}$ NGAZA, Folder No.L//7/13, File No.177/1959; NGAZA, Folder No.L//7/34, File No. 7/1959.

${ }^{12}$ NGAZA, Folder No.L//7/35, File No. 663/1963.
} 
As Sätit-Humära district is a place where big development projects instituted and potential place in Ethiopia's economic development---.As the borderland in SätitHumära is free ground, no river or hill, it created fertile ground for the speedy occupation of the Sudanese police.

The frontier claims and the boundary tensions between the two countries escalated after Numieri (1969-1985) seized power in Sudan. New policies issued by the regime of Numieri frustrated Ethiopia. In the first place, Numieri's pro-Islamic policy in Africa was seen as threat to Christian dominated Ethiopia. In addition, his government continued the speedy mobilization and militarization of the border areas. Moreover, Sudan openly started arming, training and shipping material and weapons from the Arab world to the Eritrean insurgents. ${ }^{13}$ To begin with, on 12 January 1969, Sudan deployed more than one hundred and fifty troops armed with machine gun and other weapons in Vangel and Mendaye villages (Gallabat), ten kilometers far from the Ethiopian territory. Some months later, on 24 October 1970, Sudan deployed more than two hundred troops armed with heavy artillery in Gallabat, located at very close to Mätäma. ${ }^{14}$ Two days later, 26 October 1970, it deployed defense force in Merimiya, near Metema. In addition, Sudan built new garrisons in Jäbal Gäna, Suf Wuha and Lugedi (located at five kilometers far from Gällan Zäraf) and deployed one hundred troops in each site. Moreover, Sudan built big military base in Embärkit, located very close to Rädam (Sätit), where small numbers of the Ethiopian police forces were stationed. Furthermore, Sudan built additional military base and several police stations along the Guang River. In June 1971, Sudan built several police stations in Gällaluban district, near Abderafi.

In an alarming pace, the government of Numieri continued redistributing the frontier lands claimed by Ethiopia to its nationals. In 1969, the Sudanese government expelled the Ethiopian Bétä Israeli people from Jäbal Tir and Abu Tir qebeles, Abderafi. This mechanized farming was established with the financial and technical support provided by the Israeli government to improve the lives of the Ethiopian Bete-Iraeli communities. ${ }^{15}$ The communist oriented countries involved in militarizing and arming the Sudan. Yugoslavia and Russia financed the construction of the new garrison near Port Sudan. ${ }^{16}$ Moreover, Sudan landed several air crafts in Famaka, Malakal along Gambella. As one of the Ethiopian intelligence cell in Khartoum reported, the government of Numieri landed several aircraft in Malakal, except one all of the pilots were Egyptians.

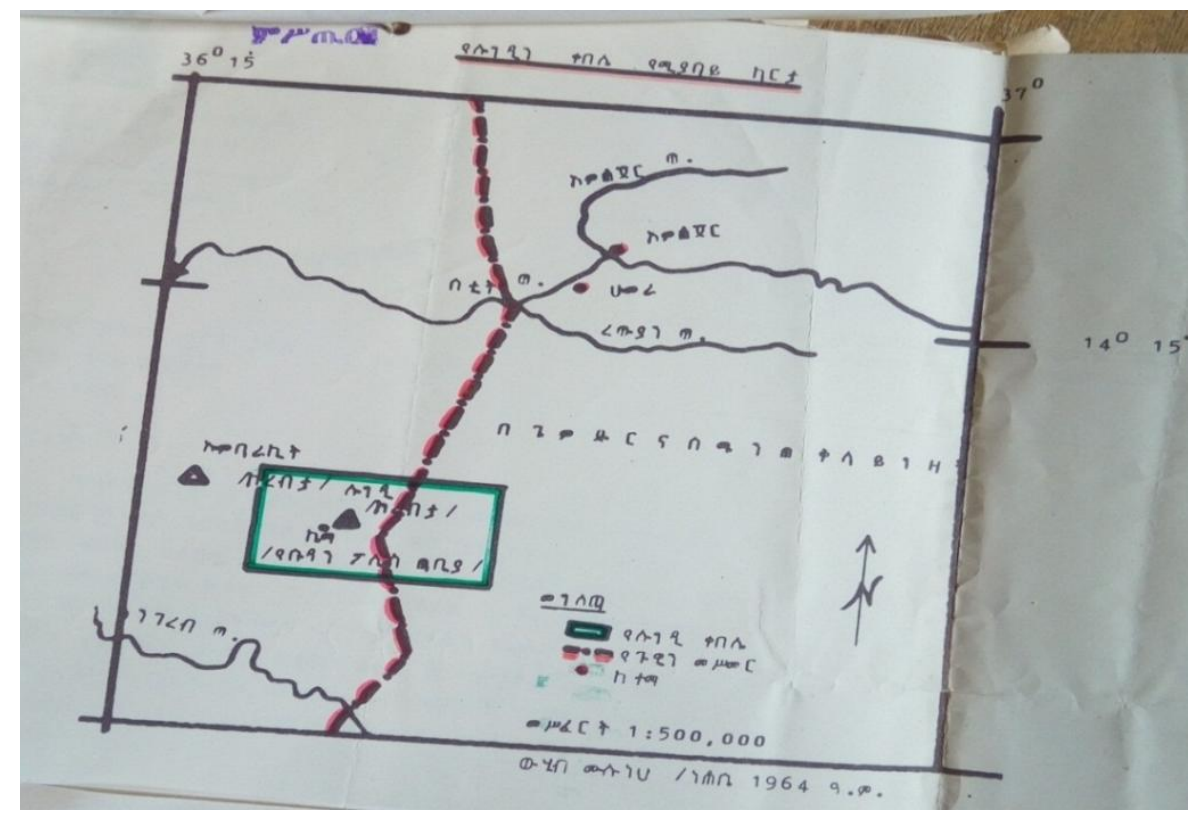

Map3: The Sudanese garrison in Embärkit and Lugdi village

Source: GTAAC L/7/35/1964 E.C.

\footnotetext{
${ }^{13}$ NGAZA Folder No.L/90, File No. 30772/1964).

${ }^{14}$ NGAZA, Folder No.L/7/35, File No. 100/57/1962; NGAZA, Folder No.L/7/35/74, File No. 57/1962.

${ }^{15}$ NGAZA, Folder No.L/3/36, File No. 01359/1962; NGAZA, File No.L/7/36/46, File No. 60/1962)

${ }^{16}$ Ibid.
} 
All these developments unequivocally necessitated Ethiopia to respond equivalently. Accordingly, the Ethiopian government shifted some sections of the Second Army Division from Eritrea to SätitHumära on 6 August 1972. In its $145^{\text {th }}$ meeting of the national defense force, it was decided to shift one battalion unit from Eritrea to Sätit-Humära to defend the territory and preserve the status quo from the Sudanese attack. Situating its major base in Sätit-Humära, responsible toBrigader General Märid Gizaw, Chief of the Second Army Division in Eritrea some sections of the army units were deployed in Gällan Zäraf, Rädam and Abderafi. This was planned to check the unconditional attacks of the Sudanese and spy the daily developments in the borderlands of Sudan. In addition, it was planned to provide security protection to Ethiopian farmers cultivating in the contested area of the Sätit.

The Sudanese activities inside the territory of the Guang River galvanized the public protest among the people of Welkait and Armačiho. Several contemporary documents revels that the Guang River has been the common boundary between the two countries since earlier times. ${ }^{17}$ In their voice reported

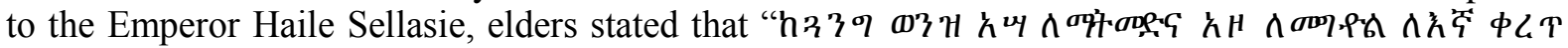
"ehs. $4 \cap C$ " (They were paying tribute to us to practice fishing and hunting crocodile on the Guang

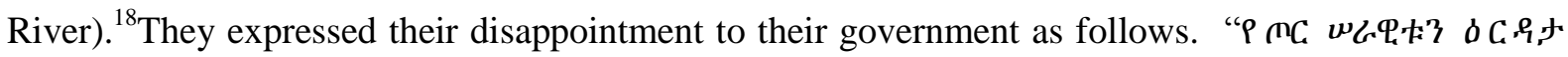

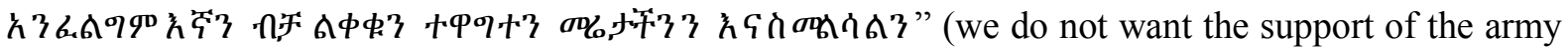
unit, leave us alone, we will return our land through fighting). ${ }^{19} \mathrm{On}$ its part, the government did not sought to provoke the war, rather hoped to use diplomatic pressure. When the Ethiopian government failed to provide the security protection, peasants armed themselves started retaliatory actions. In the late December 1968 and the early January 1969, the Ethiopian peasants destroyed the Sudanese farmlands and set fire to their houses in Greater Fashaka.

\section{Negotiation And Demarcation AtTempts: EFForts, Challenges and Failures}

Boundary tensions and frontier claimsalong Setit-Humera and Metema appeared in the late 1950s, with the beginning of commercial agriculture. In May 1958, the Sudanese government warned the Ethiopian frontier chiefs and peasants respect the Gwynn line. In the meantime, the Ethiopian frontier chiefs and peasants responded that the newly contested land belongs to them historically. Promptly, in 1964, Ethiopia notified the Sudan that the government officially invalidated the Gwynn line. Uncovering the fact, Foreign Minister, Ketema Yifru announced that Ethiopia, officially invalidated the Gwynn line and call for the demarcation of the new boundary. In his public speech, appeared in the Ethiopian Herald issued on 9 July 1964, Ketema Yifru stated the invalidating the Gwynn line as follows.

The 1902 treaty the frontier between the two countries ---the Sudan government had sought the recognition of the Major Gwynn line. Major Gwynn was a British civil servant who placed large leaps of stones arbitrarily in demarcating the EthiopianSudanese territory---. Major Gwynn represented only one side, since he had not been delegated with any authority by the Ethiopian government to demarcate the boundary on its behalf. ${ }^{20}$

The Ethiopian government responded that the Gwynn line was unilaterally demarcated by only one side and violated the article two of 1902 Anglo-Ethiopian agreement, which the two contracting parties agreed to demarcate the boundaries in the presence of representatives from both sides. With measures, in 1964 Katema Yiferu, State Minister of Foreign Affairs and Sayid Mohammed Mahjoub, Foreign Minister of the Sudan held a brief discussion in New York during the UN summit. During this short talk, they raised the boundary problems and agreed to settle any emerging threats diplomatically.

To this end, the Ethiopian government dispatched its diplomatic mission to Khartoum in July 1965. Shortly, the Sudanese delegation led by Sayid Mohammed Ahmed Mahjoub, Foreign Minister paid a state visit to Addis Ababa from 26-28 July 1965. The delegates of the two countries signed Joint Communiqué on 28 July 1965, where they agreed to stop releasing the hostile propaganda, expel the rebel forces each other from border areas. Moreover, the delegates of the two countries agreed to respect the "boundaries as defined in the existing treaties, agreement of protocols. They pledged that

\footnotetext{
${ }^{17}$ NGAZA, Folder No.4/7/90/12, File No. 02065/1961).

${ }^{18}$ NGAZA, Folder No.८/7/3/2/33, File No.2191/1961).

${ }^{19}$ NGAZA, Folder No.L/7/3/2/33, File No.2191/1961, Folder No. L/7/90/12, File No.02065/1961).

${ }^{20}$ The Ethiopian Herald, 9 July 1964.
} 
neither party should engage itself or allow its own nationals or nationals of the other party or any foreign state or any other person or institution within its jurisdiction to engage in any type of activities that are harmful or designed to harm the national interests of the other parties. In the meantime, the two countries established the Joint Boundary Commission (JBC) and Joint Ministerial Consultative Committee (JMCC), the Joint Boundary Commission of Experts (JBCE) composed of technical experts and political officers. The newly established task forces were given the responsibility to demarcate and fix the boundary marks between the two countries.

After a brief field survey, the JBC identified the contested farmlands and recommended the two countries to rectify the Gwynn line. The Foreign Ministers of Ethiopia and the Sudan approved the recommendation of the JBC for the commencement of the boundary rectification. With this important step, the JMCC held its meeting in Addis Ababa on 25 April 1966. The joint discussion was, however, faced crisis on the procedures needed to demarcate the boundary. A month later, the JMCC held the second meeting in Khartoum from 24-26 June 1966, where they agreed to commence the demarcation in the next October, after the rain stops dropping. In the meantime, they agreed to respect the status quo "without prejudice to the treaty and protocol rights of either party.

In spite of all the efforts, the JBC could not move steps forward. Conflict of interest and the divergent views appeared during the infant stage. The divergent views appeared in the nature and the process of the demarcation. The Ethiopian representatives sought the demarcation of the entire Ethio-Sudanese boundary from the north to the south with the major rectification of the Gwynn line, while the Sudanese was arguing for the re-demarcation and re-fixing of the Gwynn line boundary marks with minor or no rectification. On the contrary, the Ethiopian representatives preferred to mark the boundary limits first north of the River Setit. Besides, Ethiopia refused to handover any farmlands currently under cultivation to the Sudan. With the emergence of conflicting interests, the Sudanese government announced call for an urgent meeting of the JMCC. Accordingly, the JMCC held summit from 28 December 1966-3 December 1967. The join talks were focused on the need to respect the status quo, stop their respective peasants from occupying new farmlands and respect the ground rules signed in Khartoum in June $1966 .^{21}$

However, the JBC could not move forward. The border areas were unsafe, separatist forces were threatening the border areas. Above all, cross-border cattle raids and counter responses between SetitHumera, Metema and Quara on one hand and the Sudanese border communities of Kassala, Gedarif, Sennar and the Blue Nile expanded at an alarming rate. In addition, both Ethiopia and the Sudan took no practical measures to expel rebel forces from the border areas. In the meantime, the Sudanese frontier nationals supported by the state police harassed the Ethiopian peasant laborers in SetitHumera, took most of them as prisoners, and confiscated tractors, crops, cattle and agricultural tools. ${ }^{22}$ In response, the Ethiopian peasants penetrated into Al-Fashaqa, claimed by the Sudanese and caused public protest in Khartoum. The media and press releases in the Sudan and Egypt broadcasted that Ethiopia invaded the Sudanese land.

Shortly, Sudan deployed its national army in the border areas. In response, the Sudanese government deported the Ethiopian females who were working at several business centers in the Sudan. In March and April 1967, Ethiopia and the Sudan started exchanging aggressive words, accusations and counter accusations, mistrust, suspicion and hostility widespread. Moreover, the Sudanese media, Radio Omdurman started releasing anti-Ethiopian propaganda. In response, the Ethiopian government issued all forms of support to the South Sudanese guerilla fighters called Anya-Nya, meaning poisoned snake. In April 1967, Aklilu Habtewold, the Prime Minister of Ethiopia send lengthy diplomatic letter to the Sudanese Prime Minister, Sayid Saqiq Al-Mahdi, which describes widespread allegations in the border areas and the need to settle boundary tensions diplomatically. In response, President Al-Azhari put preconditions to start border diplomacy. In his letter written to Emperor Haile Sellasie dated on 4 June 1967, President Al-Azhari demanded the latter to immediately pull out the Ethiopian police forces from Redam, Gelan Zeraf and Abderafi.

With these initiatives, the leaders of the two countries held talks in Khartoum, 29-30 July 1967.In the meantime, they agreed to reactivate JBC and other ad-hoc committees to resume projects as in a fresh

\footnotetext{
${ }^{21}$ BeleteBelachew, 2012, "Ethiopia in African Politics, 1956-199118”.PhD Dissertation in History, AddisAbaba University, 39-40.

${ }^{22}$ NGAZA, Folder No.L//7, File No 45/1961.
} 
manner. In addition, they agreed to respect the status quo. However, they agreed to stop their respective frontier nationals from occupying new farm land. Similarly, the two parties agreed to refrain from releasing any hostile media outputs and hosting the rebels, which could affect the good neighborhood of the two countries.

With all the political endeavors, the JBC, JCC and other ad-hoc committees were reactivated. In the meantime, the Ethiopian and the Sudanese delegations agreed to respect the international law. To this end, an ad-hoc committee composed five members were formed to review the attempts of previous projects, re-examine colonial treaties and recommend the possible solutions. An ad-hoc team carried out extensive examination on the body of 1900, 1901, 1902 and 1903 and 1909 agreements.

Eventually, complications and deadlocks appeared as Ethiopian declined to accept the 1903 and the 1909 colonial treaties. Divergent views appeared in the nature of the colonial treaties signed in 1900, 1901, 1903 and 1909. The debate between the representatives of the two countries was heightened over the boundary drawn from Abu Gamal to the River Setit and then from the River Setit to the Blue Nile. The representatives of the two countries had different understandings of the concept of the colonial agreements. The Ethiopian representatives accepted the 1900 and 1901 treaty as the basis for demarcation, while the Sudanese delegates were in favor of the 1903 and 1909 treaty. The Ethiopian representatives had uncovered the fact and responded that the stretch of boundary from Tomat to Todluc, demarcated by Major Gwynn in 1903 was done without the knowledge of Ethiopia.

The treaty signed on 10 July 1900 between Ethiopia, Britain and Italy, which describes about the modification of the territory between Tomat-Todluc line was accepted by the Ethiopian representatives as a basis for demarcation. Article one states the modification of the boundary between Ethiopia and Eritrea along the Tomat-Todluc line, where the line runs from Khor Um Hajar to the confluence of the River Setit and Maietebe leaving Mount Ala Tacura to the Eritrean side. From the intersection of the River Setit and Maietebe, the boundary directed to the southward and defined at the meeting point of the River Maietebe and Mai Ambessa leaving Kunama tribes to the Eritrean side. ${ }^{23}$ Similarly, on 16 April 1901, Ethiopia and Italy modified the frontier claims, which they agreed to draw the line from Abu Gamal to the intersection of Khor Um Hajar and the River Setit. Ethiopia accepted these two colonial treaties, where Emperor Menelik II put his seal.

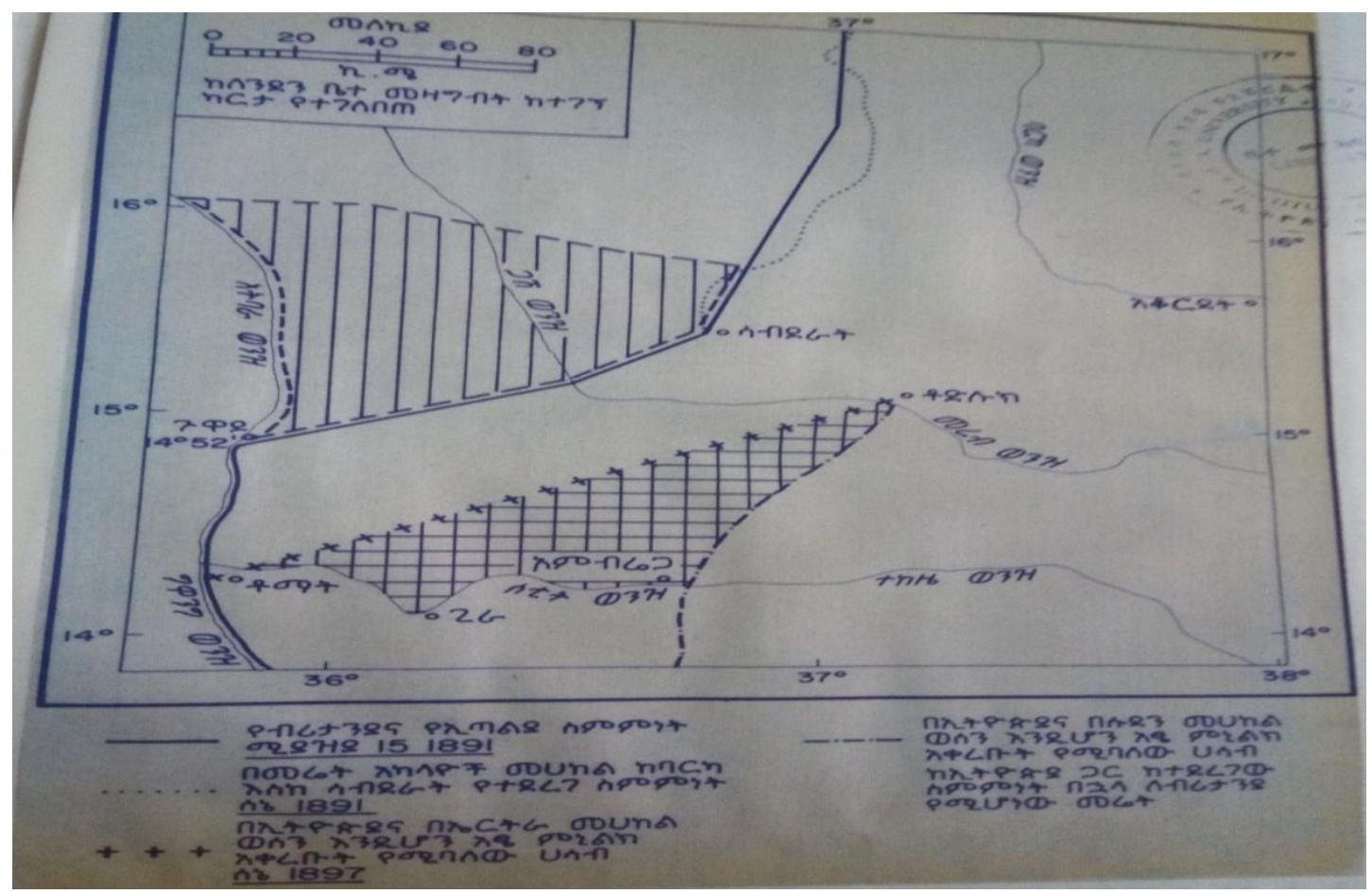

Map4: The contested Todluc-Tomat and Abu Gamal-Setit and Khor Um Hajar territory

Source: Mesfin Wolde Mariam, Ye Ethiopia ena Ye Sudan Yeteref Kartawoch (Maps of the Ethio-Sudanese Frontiers) (Unpublished, Addis Ababa, 1975).

${ }^{23}$ Hertslet, E.The Map of Africa by Treaty, Volume II (Third Ed.).(London: Frank Class \&Co.LTD, 1967), 433. 
After Nimeiri Nimier seized power in 1969, the border diplomacy was interrupted. The Sudanese frontier settlers violated the status quo and continued the further expansion of the farmlands towards Setit Humera, Metema and Quara. The growing of border threats, political contradictions and separatist forces necessitated Ethiopia and the Sudan to revise their foreign policy. In the late 1971, they took some initiatives and signed a series of treaties to work on multifaceted issues. At the invitation of Emperor Haile Sellasie, Nimeiri visited Addis Ababa in November 1971. The emperor who was well versed with diplomatic experience influenced the Sudanese government to settle the political contradictions in the South Sudan, stop backing Eritrean separatist forces and resume the boundary negotiation process. The emperor paid a state visit to Khartoum in January 1972. In March 1972, the two countries signed the historic agreement in Khartoum, which they agreed to stop financing the separatist forces one against the other.

Along with this progress, the emperor and Nimeiri sought to settle the ongoing boundary tensions between the two countries. Between 17-25 July 1972, the Joint Ministerial Consultative Committee (JMCC) held a meeting in Addis Ababa. Accordingly, in July 1972, the JMCC held summits in Addis Ababa, where Ethiopia came up with the new proposal. Its Minister of Foreign Affairs, Dr. Minasie Haile, announced Ethiopia's plan to shift its former position and the basic acceptance of the Gwynn line. ${ }^{24}$

The Ethiopian government seemed changed its position towards the Gwynn line not based on the mass decision; rather it seemed to propose by a few elites for political calculations. The political and economic implications of the decisions seemed not exhaustively examined. The breaking news leads to dispute between the Ethiopian high level authorities. In 1972, the Ethio-Sudanese boundary problem was becoming a hot agenda in the parliament meeting for the first time since the foundation of the chamber of deputies. Some members of the parliament who were not happy with the new decision notified that any intention to accept the Gwynn line would have no acceptance on their part. They argued that Ethiopia should not hand over any territories to the Sudan, which had been cultivated by the Ethiopian frontier peasants in prior years.

The frontier people lost trust on the government as no rooms were given for them to express their voice. The Ethiopian government kept the issue as the top state secret, fearing that it would provoke mass anger. The new boundary arrangement caused far reaching consequences. Rumors were widespread that the Ethiopian government agreed to handover all the contested farmlands to the Sudan. Some vibrant nationalists in Addis Ababa and Begemidir and Semien put pressure on their government to look at other options. In 1973, the waves of public protests appeared in Setit-Humera, Metema and Quara, Begemidir and Semien province. Eventually, border clashes appeared between the peasants settled on the both sides of the border from the Setit to Quara. The Ethiopian peasants settled in the border areas fired the Sudanese peasants. In the Setit area, the bloody border clashes appeared between the peasants settled in Kassala, Sudan and Tesenai, the province of Eritrea on the eve of the entry of the rainy seasons. At the same time, the bloody border clashes appeared between the peasants at Nefes Gebeya, Quara-Metema belt.

The cumulative political developments affected fieldwork schedule. The Ethiopian government asked the Sudan excuse for unconditional violence and disorder in the border areas committed by its borderland communities and the resultant delay in the field work. The JMCC reactivated technical committee and appointed them to identify the limits of the status quo, mark the farmland limits, settlement pattern and the nature of the cultivated lands on both sides of the borders. The JBC held summits in Addis Ababa from 30 June-10 July 1973 and drafted an action plan to commence the final demarcation. In the meantime, the JBC agreed to partition the whole Ethio-Sudan boundary into four zones. Accordingly, the frontier territory extending from Ras Kassar in the north to the Sätit-River was defined as northern section, while from the Sätit River to Mount Daglash was noted as the northern middle border zone. The stretch of boundary from the Mount Daglash to the intersection of the Pibor and Akob Rivers was defined as the southern middle part and the last section, described as the southern border zone runs from the confluence of the said rivers to the tri-juncture of the Lake Rudolfo (Ethiopia, Kenya and the Sudan boundary.

Regarding the stretch of boundary from the River Setit to Abu Gamal, the JBC proposed to accept the Talbot-Martinelli line demarcated in 1903 and intensified in February 1916.However, divergent views

\footnotetext{
${ }^{24}$ Brownlie, 877.
} 
appeared on issues related with the commencement of field work and where to start re-demarcation. The Sudanese members sought to re-demarcate first the northern middle section, from the Setit River to the Mount Daglash applying the cadastral survey of cultivated land following the western farmland limits tilled by the Ethiopian peasants as the status quo, while the Ethiopian parties were opting to demarcate first from the Mount Daglash to southward. Regarding the stretch of boundary from Mount Daglash to the northward, Ethiopia sought to make minor rectification using the triangulation method, where the line shall pass through the top of the Mount Umdoga, Halawi (Ethiopians called Nefes Gebeya), Jalauma, Mutana and Jerok because the former boundary line demarcated by Major Gwynn totally left these mountains to the Sudanese side and penetrated three kilometers distance into Ethiopia. They put schedule to start re-demarcation in the coming October, after the end of rainy seasons. However, the September schedule was failed because of the change of politics in Ethiopia, the old regime was ousted on 12 September 1974. The change of politics affected re-demarcation project. The Ethiopian members of the JBC, JMCC and other experts were jailed or left the country because of the political measures taken by the new military junta, Derg. As a result, boundary issue during the Derg period took new image.

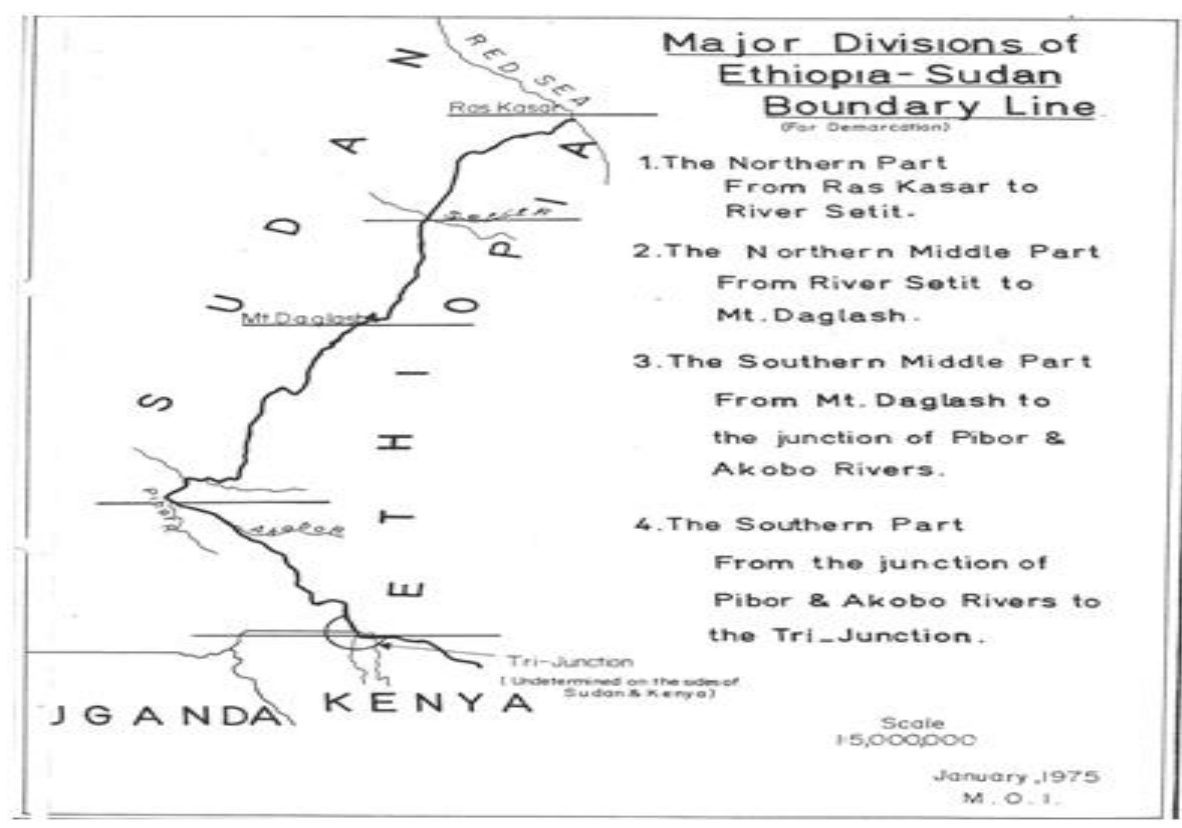

Map5: Division of the Ethio-Sudan border areas into four zones

\section{CONCLUSION}

Although Ethiopia and Sudan, neighboring countries share several common values in their history, the border issue is still the source of cooperation and hostility two countries. The long stretch of boundary, which they share, appeared as a hot agenda in the Ethiopian and the Sudanese politics since the 1950s with the beginning of agricultural revolution in Metema and Setit-Humera. On the Sudanese part, following its independence in 1956, the government developed aggressive policy towards the uninhabited sections of frontier territories. Both Ethiopia and the Sudan issued the speed possession of the frontier territories which had not yet been inhabited in the earlier years. When understanding between the two countries declined, the Sudan and Ethiopia started backing the Eritrean and the South Sudanese insurgents' one against the other. When the Sudanese government declined to refrain from threatening border communities, the imperial government started arming the local näč läbaś units to defend the border and maintain the status quo. As long as the Sudanese government continued checking its national interest, the Ethiopian government deployed police force and the defense army in 1967 and 1972 respectively. On the other hand, Ethiopia and the Sudan held diplomatic talks to settle frontier claims and boundary tensions since the early 1960s. In 1965, the two countries established the Joint Boundary Commission of Experts and the Joint Ministerial Committee, given the mandate to demarcate and fix the boundary. The boundary negotiation project, however, faced an intricate political crisis and divergent views. Members of the assigned task forces could not reach common understading on 1902 Anglo-Ethiopian treaty, the 1903 demarcation and the issues of the authorization of Major Gwynn. In an alarming situation, the frontier claims and boundary tensions 
between the two caused heavy destructions and allegations in the border areas. It caused mistrust and suspicion between the two countries and the initiatives for redemarcation is unsuccessful so far due due to the conflicting interests and successive regime changes appeared in both sides of the countries.

\section{REFERENCES}

\section{Primary Sources: Archives}

\section{A. North Gondär Administrative Zone Archives (NGAZA)}

[1] Sätitena Mätäma Wosän Atäbabäk:L/7/35/720/;L/35/459;L/7/35/388; L//7/35/716; L/7/35/100; L/7/35/663; ८/7/35/74८//7///35/3417; L//7/13/177; L//7/34/7; ८/7/35/474; ८/7//456.

[2] Täräf Woyem WosänL/7/35/663/; L//735/562; L//7/8/149/35; L//7/10/39; L/7/45/634; L/7/36/141; ᄂ

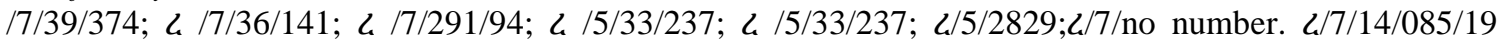
<. $/ 7 / / 86 / 110$.

[3] Yä Ethio-Sudan Dinbär GudayL/7/35 L/5/35/708; L//7/35/709; L/7/35/150/1965; L/7/35/663; ᄂ 17/35/117/60; L/7/36/46/60; ८/7/ Yäsudan Mängist Wotadäroč be Ethiopiawian gäbärewoč silämefätsimut liyu liyu bädäl yätäderge sibisäba, Minute; L/7/35/1051; ᄂ 17/35/598; ᄂ I7/36/141; L 17/29/1044; L/7/29 Yäsudan Wotadäroč Dinbär Tisäw Silämägibat; L. 15/2829; L. 15/2523; L/7/8178;

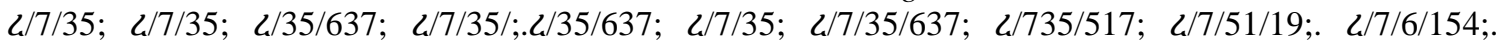
L/7/51/19/292;L/7/35/1032.

[4] Ye Ethio-sudan DinberL/7/8427/4331; L/7/8178; L//7/8/14935;L//7/8427/4331; L/7/51/19/175; L/7/16248/1964; L/7/51/19/167; L/90/30772/1964; L/7/51/19/L/7/449; L/7/6/15; L/7/51/19; L/7/449/7;

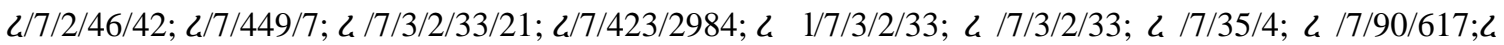
17/90/223.

[5] Yätäräf BotawočL/3/36/01359; L//7/51/19/292; L/7/3/31; L/3/90/; L/3/215/; L/3/50/;/hn/1576/4633; L/

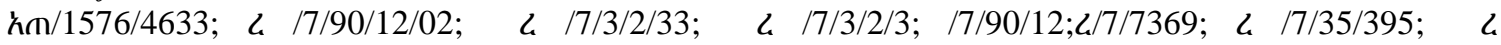

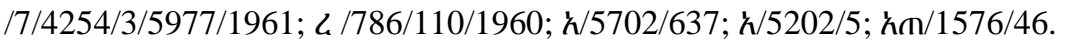

\section{Secondary Sources: Journal Articles, Books and Research papers}

[1] BeleteB. "Ethiopia in African Politics, 1956-199118".PhD Dissertation in History, Addis Ababa University, 2012.

[2] Bradley P. "Toward an Understanding of Borderland Processes" American Antiquity, 71(1),2006: 77-100.

[3] Brownlie, I. African Boundaries:A Legal and Diplomatic Encyclopedia.London:Christopher Hurst, 1979.

[4] Fredrik B. "Boundaries and Connections." In Signifying Identities: Anthropological Perspectives on Boundaries and Contested Values, edited by Anthony P. Cohen, page,17-36. London: Rutledge, 1999.

[5] Hertslet E. 1967.The Map of Africa by Treaty, Volume II (Third Ed.). London: Frank Class \&Co. LTD, 1967.

[6] Marcus H.1963. "Ethio-British Negotiations concerning the Western Border with Sudan, 1896-1902" The Journal of African History, 4 (1), 1963: 81-94.

[7] Martinez, O. Border People: Life and Society in the U.S.-Mexico Borderlands. Tucson: University of Arizona Press, 1994.

[8] MesfinWolde Mariam, Ye Ethiopia ena Ye Sudan Yeteref Kartawoch (Maps of the Ethio-Sudanese Frontiers) (Unpublished, Addis Ababa, 1975).

[9] Mulatu W. "This Land is My Land: the Ethio-Sudan Boundary and the Need to Rectify Arbitrary Colonial Boundaries"Journal of Contemporary African Studies, 2016.

Citation: Alemayehu Erkihun. "The Boundary Tensions and Frontier Claims between Ethiopia and the Sudan, 1950s-1974: The Case of Sätit-Humära and Mätäma". International Journal of History and Cultural Studies (IJHCS). vol 5, no. 4, 2019, pp. 1-12 doi: DOI: http://dx.doi.org/10.20431/2454-7654.0504001.

Copyright: (1) 2019 Authors. This is an open-access article distributed under the terms of the Creative Commons Attribution License, which permits unrestricted use, distribution, and reproduction in any medium, provided the original author and source are credited. 